Trinity University

Digital Commons @ Trinity

School of Business Faculty Research

School of Business

6-2016

\title{
RunTex: A Community Landmark Run Out of Business
}

Emily S. Sparvero

Stacy Warner

Jacob K. Tingle

Trinity University, jtingle@trinity.edu

Follow this and additional works at: https://digitalcommons.trinity.edu/busadmin_faculty

Part of the Business Administration, Management, and Operations Commons

\section{Repository Citation}

Sparvero, E. S., Warner, S., \& Tingle, J. K. (2016). RunTex: A community landmark run out of business. Sport Management Review, 19(3), 343-351. doi: 10.1016/j.smr.2015.10.003

This Post-Print is brought to you for free and open access by the School of Business at Digital Commons @ Trinity. It has been accepted for inclusion in School of Business Faculty Research by an authorized administrator of Digital Commons @ Trinity. For more information, please contact jcostanz@trinity.edu. 


\section{Running head: RUNTEX}

\section{RunTex: A Community Landmark Run Out of Business}

Keywords: business models; strategic management; community relations; social responsibility 
The case follows Paul Carrozza and his journey in building a once highly successful running shoe store in Austin, TX. The case presents newspaper accounts and other publicly available information regarding Carrozza and the store he built and ultimately had to close, RunTex. Specifically, the case offers both undergraduate and graduate students the opportunity to evaluate the repercussions of a business that fails to engage in strategic planning. As a result, this case provides the ideal backdrop for instructors to convey the significance and obligation for future sport managers to understand the importance of strategic management. The case is primarily intended for use in Strategic Management, Organizational Behavior, and/or Sport Marketing courses wishing to highlight CSR strategies. 
Teaching Note

This case challenges future sport managers to consider the importance of strategic management to fundamental business practices. The case presents factual information related to RunTex, a once-thriving Austin, TX based running store. The case highlights and provides students with the opportunity to critique the failure of a business to engage in strategic planning. Thus, this case can be used in both undergraduate and graduate courses and provides an example for instructors to highlight the importance and necessity of strategic management. Students will examine: 1) the sources of competitive advantage as they relate to RunTex; 2) how a small business in the sport industry should engage in strategic planning; and 3) the relationship between business development, community development, and social responsibility.

Keywords: business models; strategic management; community relations; social responsibility

After successfully completing the case, students will be able to:

- Articulate the importance for sports businesses to focus on developing and sustaining competitive advantage;

- Identify and discuss issues related to strategic management in small businesses; and

- Discuss how small businesses can effectively utilize strategic corporate social responsibility.

\section{Sources of competitive advantage and internal analysis}

According to Porter (1987), the aim of competitive strategy is "to establish a profitable and sustainable position against the forces that determine industry competition" ( $\mathrm{p}$. 1). This case allows students to conduct an internal analysis of RunTex and identify the key determinants of a competitive advantage among firms in the running footwear/apparel industry. 
Porter's generic strategies (i.e., cost leadership, differentiation, focus) provide a useful starting point for discussions regarding competitive advantage. The two basic types of competitive advantage are (a) cost leadership and (b) differentiation. A firm that adopts a cost leadership strategy offers equivalent benefits as competing firms at a lower price, while a firm that adopts a differentiation strategy provides unique benefits that justify a higher price. Both strategies are grounded in the idea of creating value for the consumer, and the success of a strategy depends on a firm's implementation of its chosen strategy as well as its internal and external environments. Porter's third generic strategy, focus -allows for the application of either a cost or differentiation focus in a market with a narrow competitive scope.

While firms within an industry may have various strengths and weaknesses, each strength or weakness is a function of its generic strategy (i.e., cost leadership, differentiation, focus). This case can be used to provide a foundation for students to understand the distinction between strengths/weaknesses of a firm and the firm's strategy. Within the case there is an emphasis on the level of service provided by RunTex employees (as illustrated by the buying process which involved potential consumers running around the outside of store while a salesperson diagnosed their gait). Students may correctly identify this as a strength of RunTex, and instructors should encourage students to think about how this strength of RunTex is, in fact, a function of a differentiation strategy.

As students think through the strengths and weaknesses of RunTex, it is helpful to introduce techniques used to conduct internal analyses. Specifically, the value chain framework and the resource-based view of the firm can be introduced. The value chain is a framework that examines a firm's primary activities (i.e., inbound logistics, operations, outbound logistics, marketing and sales, service) and support activities (i.e., firm infrastructure, human resource management, technology development, procurement). It is through these activities that a firm can establish (or fail to establish) a competitive advantage. 
The emphasis in value chain analysis is on value, or "the amount buyers are willing to pay for what the firm provides them" (Porter, 1987, p. 38). Students can use the facts of the case to think through the value (or lack thereof) created through marketing and sales and service, as well as human resource management and infrastructure.

For example, a firm infrastructure includes those activities that make up overhead (e.g., general management, planning, accounting), and the case includes several examples of poorly managed infrastructure. Specifically, RunTex's failed expansion efforts (as evidenced by store closures) and its financial management problems (as evidenced by its failure to pay suppliers, the county, and other creditors) suggest that infrastructure issues contributed to RunTex's closure. On the other hand, RunTex's expert sales and service contributed to its success. While the case does not explicitly provide all of the information required for a complete value chain analysis, students should be encouraged to think through the value chain and identify specific activities that could have contributed to a sustained competitive advantage for RunTex. The value chain analysis could be an activity for students who have taken a supply chain management course, while instructors of students without this background would likely find the case useful for introducing the concept of value chain analysis.

A complementary approach to internal analysis is grounded in the resource-based view of the firm. Firm resources include everything that is controlled by the firm that improves its efficiency and effectiveness (e.g., assets, capabilities, organizational processes, information, knowledge) (Barney, 1991). A firm's resources must be valuable, rare, inimitable, and organized (VRIO) in order to create a sustained competitive advantage. A resource is valuable if it increases revenues or decreases costs; a resource is rare if it is an unique skill or asset that cannot be simultaneously possessed by many rival firms; a resource 
is inimitable if it cannot be copied by rivals; and a resource is organized if it is structured in a way to execute and protect its source of advantage (Barney, 1991).

In the case of RunTex, its owner Carrozza was one resource that met the VRIO criterion. (Instructors are encouraged to show the 7-minute video bio of Carrozza referenced at the end of the CSR section, when discussing this point.) An argument can also be made that the geographic locations of RunTex's most successful stores were also VRIO.

Unfortunately for RunTex, many of the firm's other resources were not VRIO, which allowed Luke's Locker (with superior infrastructure activities and competitive marketing, sales and services in the value chain) to erode RunTex's competitive advantage.

For instructors that wish to have students focus more on the competitive advantage and internal analysis in case, Barney (1991), Barney and Clifford (2010) and Woolf (2008) would be prerequisite readings to consider assigning students. Barney (1991) in particular provides a very thorough and strong overview of sustained competitive advantages, while Woolf (2008) offers specific insight on differentiation in the health and fitness field. Meanwhile Barney and Clifford (2010) is an engaging text on business strategy that instructors also could assign prior to the case. Instructors would likely find that all three of these suggested supplemental readings would add greater depth to student responses and class discussion regarding the case.

Discussion questions:

1) What resources and capabilities contributed to RunTex's competitive advantage (which it held until 2008)?

a. To what degree were those resources and capabilities rare, valuable, imitable, and organized?

Students may identify a variety of resources and capabilities, including employee expertise, support services, attractive geographic locations. Unfortunately, many 
of RunTex's resources and capabilities failed to meet the VRIO criteria. For example, the level of service provided RunTex employees initially gave RunTex an advantage and contributed to its unique brand. However, this level of service could be imitated by competitors, or - more directly -- RunTex employees could be recruited to work for competitors. Carrozza (and his ability to build relationships in the local community and the running community) represents a human resource that is rare and inimitable, but given Carrozza's reluctance to treat RunTex primarily as a profit-oriented enterprise, students may question his value.

2) Explain how RunTex's competitive advantage was eroded.

a. What generic strategy was employed by Carrozza? Carrozza executed a differentiation focus strategy. The value of the unique benefits provided to the consumer (including custom fitting and support services) more than offset the higher prices and allowed RunTex to occupy a unique space in the industry. Evidence from the case to support this includes Carrozza's statements such as "it's really important to us to get people in the right shoes" and his emphasis on RunTex University and RunTex events. Instructors should ensure that students identify that this differentiation strategy was initially a strength for RunTex.

b. Could Carrozza have simultaneously pursued both a cost leadership and differentiation strategy? With Carrozza's emphasis on service, cost leadership would not be feasible. Some students may be tempted to argue that the inclusion of "free" services, including those associated with shoe fittings and the in-house training programs could be evidence of a cost leadership strategy. Instructors should emphasize that these value-added services are- 
in fact-evidence of differentiation. Further, the demographic information provided in the case shows that frequent runners typically have high household incomes, which suggests that they are less price sensitive. This gives support to the potential success of Carrozza's differentiation focus strategy. Instructors should also remind students that in most cases, in order to achieve a competitive advantage through cost leadership, a company must be the cost leader, not just a company that has low prices. A company like RunTex would find it very difficult to be the cost leader because of the economies of scale realized by larger companies and the competition from online retailers.

c. Could any firm successfully pursue both? Porter would argue that it is very difficult to simultaneously pursue both strategies. In order to do this, there would likely need to be different brands under the same umbrella, as is commonly the case in hotels (e.g., Hilton family of hotels has luxury brands, like the Waldorf Astoria, mid-range brands, including Doubletree and Embassy Suites, and value brands, including Hampton Inn).

3) What resources and capabilities could Carrozza have brought to his newest venture (e.g., fusing technology and running)? The case and supporting videos emphasize Carrozza's personal charisma, passion for health, and ability to build relationships within the community. These could facilitate any new venture Carrozza chooses to pursue in the future. Students may identify a variety of different resources and capabilities, but they should think about them in terms of VRIO. Carrozza's personality, passion, and relationship skills should be identified as strengths and pursuing VRIO resources recognized as opportunities. 
4) Explain if RunTex effectively provide support services (e.g., fitness testing or race training) to its customers and used this distinguished themselves? RunTex distinguished itself by blending support services (e.g., free training programs, injury evaluation clinics, sports massages) with its retail and event business. However, whether or not this was effective is debatable. One possible argument is that Carrozza effectively served the running community (and community at large) without necessarily building RunTex's customer base. The challenge for RunTex was providing these support services in a strategic way and leveraging them to drive its primary business.

5) Describe how a strategic use of support services could have helped RunTex maintain its competitive advantage. If Carrozza had been more strategic in using these services to drive revenues, he may have been better able to retain those employees who ultimately founded their own small businesses. In doing so mitigating a potential threat. Students should be encouraged to think across the organization's functions for ways in which the support services could be leveraged. Some examples include: engaging the corporate community for sponsorships, offering a structured membership system with different services available for different membership levels and fees. Instructors should emphasize the importance of translating the support services into tangible revenue. As students complete their analysis of the case, instructors are encouraged to have students consider better leveraging support services as a potential opportunity.

\section{Strategic planning in small businesses}

Byers and Slack (2001) identify key challenges to decision-making in leisure-oriented small businesses, and their work demonstrates for students specific strategic management concepts that are particular to this segment of the sport industry. An April 2014 report from 
Mintel Research found that consumers in the United States increased their spending on recreation and leisure by approximately $9.8 \%$ from 2008 to 2013, resulting in total consumer expenditures on leisure of $\$ 335.77$ billion in 2013. The size of the recreation and leisure industry suggests that it is worthy of attention and discussion, and this RunTex case illustrates many of the challenges identified by Byers and Slack. Specifically, Carrozza (similar to $95 \%$ of the business owners referenced in the article) was driven by a hobby motive and lacked managerial experience. Interestingly, whereas businesses in the Byers and Slack article were reluctant to pursue expansion, Carrozza's expansion plans played a large part in the demise of RunTex. Consequently, instructors that wish to highlight planning for small businesses in the sport industry should consider Byers and Slack (2001) as a required assigned reading with the case.

Discussion question:

1. To what extent do you believe that the experience of Paul Carrozza and RunTex is consistent with the findings of the Byers and Slack article. Identify and list specific constraints to strategic decision-making facing small businesses in the leisure industry.

Students should identify the following parallels between the RunTex case and the Byers and Slack article: lack of distinction between personal and professional objectives and time constraints.

2. Based on the facts presented in the case, do you believe that the success and sustainability of RunTex was affected by these specific constraints? Explain why. Answers will vary, but instructors should highlight the lack of strategy, planning, and focus that is demonstrated in the case.

Suggested Activity: 
Using only the data from the Appendices and the information presented in the case, conduct a brief SWOT analysis of RunTex. Given the analysis, what strategy would you recommend RunTex focus on for the next 3-5 years (for your analysis, assume that the intention is for RunTex to remain a growing business)?

Instructors should expect that students identify Carrozza's personality, passion, and relationship skills along with RunTex's initial differentiation strategy as strengths. Weaknesses could include Carrozza's lack of business savvy and a clear strategy while pursuing VRIO resources and better leveraging RunTex's support services should be recognized as opportunities. Other opportunities include socio-cultural factors (e.g., the increase in female participation in running) and the geographic location and climate in Austin, which contributes to the city's reputation as an active city. Threats would include Luke's Lockers and all the entrepreneurial endeavors of former RunTex employees that are highlighted in the case, as well as the growth in online retailers (as shown in Table 2).

\section{Strategic corporate social responsibility}

Corporate Social Responsibility (CSR) activities that are strategic in nature have the potential to benefit both the organization engaged in the activities and also the issue, cause, or organization that is the beneficiary of the CSR initiatives. There has been a great deal written about the CSR activities of professional sport organizations; however, this case provides the opportunity to consider the benefits of CSR to a different type of business in the sport industry. In particular, this case allows students to consider whether being a good corporate citizen is necessary and/or sufficient for a firm like RunTex to establish competitive advantage. RunTex viewed its community-oriented activities as philanthropy, with little to no effort made to leverage these activities to drive sales. This represents a missed opportunity for RunTex. Additionally, Carrozza's commitment to various community 
activities diverted the time and attention of RunTex employees from their primary responsibilities.

For instructors that wish to use the case to highlight CSR as strategy in sport settings, Heinze and colleagues (2014) and Pegoraro and colleagues (2009) work should be considered as potential supplemental readings. The use of CSR with Detroit Lions (Heinze, Soderstrom, \& Zdroik, 2014) and the national women's triathlon series (Pegoraro, O'Reilly, \& Levallet, 2009) are highlighted in the readings. In addition, instructors wanting to have students consider the link between sponsorship and CSR should consider assigning Plewa and Quester (2011) as ancillary reading for students. Meanwhile, Porter and Kramer (2006) also would be a supplemental reading for instructors to consider, as it highlights the connection between competitive advantages and CSR. Having students read all four of the supplementary readings prior to the activity will yield more creative, detailed, and thorough analyses. Alternatively, an instructor may want to assign the Heinze and colleagues (2014) and Porter and Kramer (2006) articles to half the class and assign each of the other two readings to half the class (Pegoraro, O'Reilly, \& Levallet, 2009; Plewar \& Quester, 2011). Doing so will likely lead to greater student engagement with the case and discussion questions.

In addition to the case, it is suggested that the following video bio of Carrozza may also be shown to contextualize his impact on the Austin community: http://vimeo.com/17550783. The video was made to commemorate Carrozza receiving an Austin leadership award. The seven-minute video highlights Carrozza's career, his wellrespected character, and his impact on the city of Austin.

Discussion questions:

1) RunTex was very involved in the Austin community and generously supported a wide variety of social issues and nonprofit organizations. However, RunTex's reputation as a good neighbor was insufficient to protect its competitive advantage. To what 
extent were the CSR activities of RunTex strategic? Provide a critique RunTex's CSR activities and suggest ways in which they could have been improved. Students should note that, although RunTex had a positive impact on the local community, its CSR activities, much like the company's expansion plans, were not strategic from a business perspective. This is particularly the case with sponsorship of the Trail of Lights, which lacks a fit with the core business. Instructors can return to Carroll's (1991) conception of CSR, which provides the basis for discussion of whether CSR activities should be linked to business objectives in order to be considered successful. This is also an opportunity to distinguish between CSR and cause marketing.

2) Did RunTex effectively match its internal resources with external needs? Justify your answer using information presented in the case, from the supplemental readings, and the videos. To some extent RunTex did accomplish this. For example, RunTex's expert sales and service contributed to its success and met the needs of their customers. However, RunTex's failed expansion efforts and its financial management problems (e.g., failure to pay suppliers and other creditors) suggest that their internal resources did not adequately address other external needs.

3) Was RunTex involved in cause sponsorship, cause-related marketing, or corporate philanthropy? Describe the difference when detailing your answer. Student responses should display an understand of the key differences between these concepts. Cause sponsorship would occur if RunTex provided a financial contribution to a nonprofit event or program. In exchange, the nonprofit would promote RunTex's support of the cause through various marketing channels. Cause-related marketing refers to an activity/campaign in which RunTex and a nonprofit organization would align to market something for mutual benefit. Finally, corporate philanthropy is a type of giving that RunTex primarily participate in. It offers the lowest expectation of 
financial return, however, corporate philanthropy does provide a tax break.

Businesses typically take part in corporate philanthropy, that may be related or unrelated to their core business, but the owners or employees have specific interest in the cause (e.g., local impact, employee fighting a specific disease, personal interest of the owner, etc.).

4) Identify RunTex's stakeholders. How would a strategic focus on CSR impact its image with each stakeholder group? Responses should identify stakeholder groups such as customers, community members, employees, owners, etc.

Suggested Activity:

1) Assume that you were hired by RunTex as a consultant in 2008. Produce a strategic planning report that might have helped RunTex avoid its eventual fate. The report should focus on the use of Corporate Social Responsibility and include a mission statement, a vision statement, values/operating principles, specific, measurable goals, and action steps required to achieve those goals.

\section{Video updates}

Instructors may select to show any of the following videos that document the demise of RunTex from the initial eviction notices posted in April 2013 to the eventual auction of RunTex's assets:

http://www.kvue.com/story/money/business/2014/05/23/2373816/

http://www.kvue.com/story/news/2014/05/23/2373996/

http://www.kvue.com/story/news/2014/05/23/2378258/

http://www.kvue.com/story/news/2014/05/23/2379406/ 


\section{References}

Barney, J. (1991). Firm resources and sustained competitive advantage. Journal of Management, 17, 99-120.

Barney, J., \& Clifford, T. G. (2010). What I didn't learn in business school: How strategy works in the real world. Boston, MA: Harvard Business Review Press.

Byers, T., \& Slack, T. (2001). Strategic decision-making in small businesses within the leisure industry. Journal of Leisure Research, 33,121-136.

Carroll, A. B. (1991). The pyramid of corporate social responsibility: Toward the moral management of organizational stakeholders. Business Horizons, 34, 39-48.

Heinze, K. L., Soderstrom, S., \& Zdroik, J. (2014). Toward strategic and authentic corporate social responsibility in professional sport: A case study of the Detroit Lions. Journal of Sport Management, 28, 672-686.

Pegoraro, A., O'Reilly, N., \& Levallet, N. (2009). Gender-based sponsorship of grassroots events as an agent of corporate social responsibility: The case of a national women's triathlon series. Journal of Sponsorship, 2, 140-151.

Plewa, C., \& Quester, P. G. (2011). Sponsorship and CSR: Is there a link? A conceptual framework. International Journal of Sports Marketing \& Sponsorship, 12, 301-317.

Porter, M. E. (1987). From competitive advantage to corporate strategy. Harvard Business Review, 65, 43-59.

Porter, M. E., \& Kramer, M. R. (2006). Strategy \& society: The link between competitive advantage and corporate social responsibility. Harvard Business Review, 84, 78-92.

Woolf, J. (2008). Competitive advantage in the health and fitness industry: Developing service bundles. Sport Management Review, 11, 51-75. 
RunTex: A Community Landmark Run Out of Business

\section{Case Study}

Paul Carrozza has always had a passion for running, and he believed that it was his duty to share his passion by making sure that individuals had access to the best running shoes and equipment, along with access to expert advice. Early in his career, Carrozza realized that top-of-the-line running shoes were not easy to find. After arriving at Abilene Christian University and building relationships with various shoe vendors, Carrozza began selling shoes and gear from vendors to local athletes, quite literally out of his car trunk (Shields, 2008). In 1988, three years after earning NCAA Division II All-American status as a middle distance runner and graduating from college (ACU, 2012), Carrozza purchased a storefront in an effort to bring high-end running gear to Austin, TX (Grattan, 2012). See Appendix A for a timeline of events.

Carrozza's business philosophy can be summed up by the following excerpt from an article in Texas Monthly magazine:

Classes, massages, clinics...it's not that Carrozza isn't interested in selling shoes, although he has admitted, 'To me, retail is a necessary evil of our business.' Like everything else he does, his approach to selling shoes is straightforward and practical, with an eye on long-term business instead of short-term sales. Carrozza aims to increase the national average — one new pair of shoes bought every two years—not with fancy sales gimmicks, but as part of his simple philosophy of trying to get folks to run more, period: 'If you're only going to buy a shoe every two years, it better be the right one. Productwise, it's really important to us to get people in the right shoes.' (Cook, 1998)

During the first year of operation in Austin, Carrozza did $\$ 260,000$ in business. A year later sales climbed to $\$ 620,000$. Encouraged by sales more than doubling, Carrozza 
opened two new stores in 1990. However, the new locations did not experience the same success and were soon closed (Cook, 1998).

Sales rapidly increased at the original location due mostly to RunTex's communitybased approach; they developed relationships with local nonprofit groups and created their own events. The employees came primarily from the running community, and the sales staff was considered especially knowledgeable. If you entered a RunTex store to buy a pair of shoes, it was common for a sales associate to watch as you ran around the building and diagnose your specific shoe needs based on his or her observations. The initial goal of the company was to get people running and focused on fitness, a goal, which according to Carrozza, never changed (Deciutiis, 2013).

Consistent with his passion for bringing running to the masses, Carrozza founded RunTex University and RunTex Events. RunTex University started in 1995 and was geared toward teaching beginners to run and allowing those who were already runners to hone their skills. These free RunTex classes met every Monday through Thursday evening at the store. The store also offered sports massages from the Body Therapy Center, which occupied a room upstairs at RunTex store. Additionally, they provided a free injury-evaluation clinic every Friday, staffed by an orthopedic surgeon and a physical therapist (Cook, 1998). RunTex Events quickly took off as well. While Carrozza served as the race director for the first Motorola Marathon in Austin in 1992, RunTex Events provided the technical support. The success of that event led other organizations to recruit RunTex Events to assist them as they put on title events of their own. RunTex Events provided event services at reduced rates or for free for the numerous road races hosted by nonprofits. However, the registration and packet pick-up for these events were held at RunTex stores, which required race participants to physically come to the store. Once in the store, event participants could purchase any items needed for the event (e.g., Gu energy gel, BodyGlide) or other items to support their running. 
As a result of the emphasis on running instruction, race organization, and shoe retailing, RunTex experienced tremendous growth in sales - from \$2 million in 1995 to \$3.5 million in 1997 (Cook, 1998).

According to Carrozza, "[RunTex] had a formula based on running opportunities that piqued people's interests. The more events we held, the more people came into the store" (Shields, 2008). These events not only drew people to the Austin-based store, but the timing of events and location of the store were also keys to its early success. RunTex's two most successful stores were located at opposite ends of the Town Lake Hike and Bike Trail, a popular 10-mile scenic trail located in the heart of Austin (See Appendix B). It is estimated that annually over 1 million visit the trail. While this estimation includes some visitors, the primarily users of the trail are locals (National Trails Training Partnership, 2009). These key store locations allowed RunTex to serve as a social hub for the Austin running community.

In addition, RunTex was able to capitalize on growing interest in running. According to Carrozza, RunTex "hit the market at the right time, with the right energy. [It] built hundreds, if not thousands, of events in Austin. There's this proliferation of events that we started engaging the Austin nonprofit community, building the running community, engaging the corporate community for sponsorships, and it has been really a great thing. Austin's become one of the fittest cities in the nation" (Deciutiis, 2013).

Participation trends support the notion that RunTex did indeed hit the market at the right time when it opened its doors in 1988. According to a Running USA report there were 5.2 million road race finishers in 1991 in U.S. Those trends skyrocketed to a record 13.9 million in 2011, a 170\% increase in runners participating in running events (See Table 1). The number of female runners has also steadily increased and in 2010, the number of female finishers surpassed the number of male. As the number of runners increased, so did the sales of running shoes (see Table 2). Along with the favorable running trends, Austin was a perfect 
location for a store like RunTex to flourish. According to Forbes' list of Top 10 Fittest

Cities in the U.S., 78.4\% of Austinites reported exercising regularly, which is in large part due to the high number of parks and pools per capita. The city is frequently touted as a "fit city," which many credit to the well-maintained parks and greenbelts and the efforts of Carrozza and RunTex. In an article in the academic journal Environment and Planning, Herrick (2008, p. 2727) noted that the main reason for Austin receiving such a "fit city" accolade when compared to other Texas cities is that Austin has a lot of green space where people can be active and a running culture that Paul Carrozza has helped create. Herrick further highlighted that the reasons that Austin is a fit city can be traced directly to the dynamism and visibility of certain city stakeholders, among which Paul Carrozza tops the list. Herrick then explicitly noted that Carrozza is a powerful force behind the city's drive to place Austin firmly at the head of the annual Men's Fitness 'fit city' league.

Following the running trends seen nationwide, RunTex built a distinctive brand and fostered a strong running community. Carrozza's personality, charisma, and perceived business success earned him local and national recognition. He was named a member of the Texas Governor's Advisory Council on Physical Fitness, and President George W. Bush named him to the President's Council on Physical Fitness. In 2002, Carrozza was on the cover of Smart Money magazine and RunTex was named one of Inc. magazine's 22 favorite small businesses. For over 25 years RunTex was a well-recognized and respected business in Austin.

At its high point, RunTex Events produced over 120 events per year and raised over $\$ 5$ million annually for local charities. RunTex also leveraged its resources and relationships to benefit charities. For example, Carrozza was an active supporter of Move Through Cancer, a nonprofit organization through which cancer survivors and their families would train to complete either a $5 \mathrm{~K}$ or $10 \mathrm{~K}$ run. Carrozza believed that in order for a running program to be 
successful, participants had to be in the right shoes, get the right training, and work toward a specific goal. Thus, he used his relationships with suppliers to provide running shoes to participants, he contributed his employee's man hours to conduct shoe fittings, and he provided the meeting space for the group. Carrozza's dedication to the community, however, was not limited to local charities. RunTex provided water coolers along the popular Town Lake Hike and Bike Trail free of charge, a daily service that was appreciated by the thousands of locals who regularly used the trail. Additionally, in 2012, after the city of Austin announced that it would no longer host the annual Trail of Lights, a popular display of Christmas lights and vignettes in Zilker Park, RunTex agreed to be the sponsor of the event. The conditions of the sponsorship required RunTex to raise nearly half a million dollars.

Further, Carrozza's entrepreneurial spirit was contagious. Several RunTex employees who were responsible for functions that contributed to RunTex's unique position were encouraged by Carrozza to spin off their roles into separate business entities. Specifically, the employees who managed the chip-timing operations for races, race logistics and set up, and training programs all established their own small businesses to service local and regional running communities. The chip-timing and logistics companies were not in direct competition with RunTex; rather, upon the establishment of these spin-offs, Carroza entered into contractual relationships with his former employees so that they would provide services to RunTex and RunTex Events as separate business entities.

RunTex had provided these employees with the opportunity to gain knowledge and build the relationships necessary to launch their own successful enterprises, and the departure of these employees meant that key resources and capabilities were transferred outside of the company. As a result, these valuable, unique, and rare resources that were previously owned by RunTex were now available to other companies who were in direct competition with RunTex. 
The training business that was spun off into a separate company was a direct competitor. The two employees behind the training business acknowledged that they learned a lot from Carrozza which led to their success. Carrozza's response was consistent with his view of the mission of RunTex: "Austin is the best running community on the planet, and I am glad that locals and friends are growing their services to the running community," he said. "It will help us continue to be the fittest city in the nation" (Zaragoza, 2008).

The company's community-based and socially responsible approach helped establish RunTex as the epicenter of Austin's running community. Many assumed due to the wellestablished recognition, RunTex was a thriving business.

\subsection{The Failed Business: What happened?}

In the spring 2013 after operating 25 years, a lender alleged it was owed $\$ 625,000$ and filed a lawsuit against RunTex. Additionally, RunTex was evicted from its flagship store, located near the Hike and Bike Trail, for failing to pay rent and $\$ 150,000$ in judgments were issued. Subsequent news reports indicated RunTex owed $\$ 17,000$ in past-due property taxes, while some vendors were also still awaiting payments. By that time, RunTex had already closed its other store located on the Hike and Bike Trail. Carrozza has been surprisingly candid about what happened. Carrozza never planned to open a sporting goods store. As an Abilene Christian University student, he had dreams of becoming a doctor, but his love of running led him down a different path (Dinges, 2013). "I've never considered myself a retailer," Carroza said, "Sure, I've put a lot of shoes on a lot of people, but a lifestyle is what I've been selling." His lack of business savvy, Carrozza said, is how RunTex wound up in financial trouble. The increase in competition and a failed expansion only further contributed to the problems (Dinges, 2013). Without a specific growth strategy, RunTex's rapid expansion ultimately led to its failure. When business peaked in 2008, RunTex again tried to expand to five total locations without a specific business development strategy. Carrozza said 
he learned a "valuable lesson and an expensive lesson around expansion and what it takes to go from one store to five stores" (Rice, 2013). He further explained, "So we did the big expansion ... I just took on a lot, and that's really what created the stress because I didn't get the appropriate capital to do so" (Cook, 1998).

In addition, by that time the Austin running shoe market had competitors, as new running stores began to enter into the market. As one local stated,

RunTex just got out-marketed by the new kid in town, Luke's Locker, which proved a more agile and slicker company that spoke the language of the running community better and served their needs in a more compelling way. It's sad, because RunTex has done so much for runners in Austin for so long. I hope they can regain their footing (Luther, 2013).

Local runners quickly began to recognize that Luke's Locker storefront was better stocked (greater variety of shoes), offered better quality products, and had a better presence in the city, while RunTex was thought of as store that was not staying current with industry trends or offering what their customers needed. Technology also played a key role as sales via online retailers almost doubled between 2008 and 2013 (see Table 2). These online retailers were able offer lower prices on shoes by significantly reducing overhead costs.

As of July 2014, all RunTex stores were closed. The location of the flagship store became new apartments, and a pawn shop sits on the site of another former RunTex location. Still, Carrozza's passion is undiminished. He is currently planning a comeback and wants to use technology to help fitness coaches optimize training. 


\section{References}

ACU (2002, August 12). ACU alum to pace the president in fitness run Saturday. Retrieved from: http://www.acu.edu/events/news/020621_carrozza.html

Cook, D. (1998, June). Best feet forward: Paul Carrozza of Austin's RunTex is turning the state capital into the running capital of the United States. Texas Monthly. Retrieved from: http://www.texasmonthly.com/content/best-feet-forward?fullpage=1

Deciutiis, H. J. (2013, April 8). RunTex founder Carrozza about company's future despite Riverside's eviction notice. The Daily Texan. Retrieved from: http://www.dailytexanonline.com/news/2013/04/08/runtex-founder-carrozza-aboutcompanys-future-despite-riversides-eviction-notice

Grattan, R. (2012, November). Journal profile: Paul Carrozza. Austin Business Journal. Retrieved from: http://www.bizjournals.com/austin/print-edition/2012/11/23/journalprofile-paul-carrozza.html?page=all

Herrick, C. (2008). To the west and east of Interstate-35: Obesity, philanthropic entrepreneurialism, and the delineation of risk in Austin, Texas. Environment and planning. A, 40(11), 2715.

Luther, J. (2013, April 5). End Of an era: RunTex's Riverside location now closed. Retrieved from: http://austinist.com/2013/04/05/end_of_an_era_runtexs_riverside_loc.php

National Trails Training Partnership (2009). Impact of trails and trail use: A survey of Austin's Town Lake trail users. Retrieved from http://www.americantrails.org/resources/adjacent/AustinTwnLkSurvey.html

Rice, L. (2013, April 5). What's next for RunTex? Retail may become less of a priority. KUT.org. Retrieved from: http://kut.org/post/whats-next-runtex-retail-may-becomeless-priority 
Shields, C. (2008, November/December) Austin's RunTex aims to keep runners and local charities healthy. Retrieved from:

http://www.texasahead.org/texasrising/tr081112/runtex.php

Zaragoza, S. (2008, January 13). New specialty running retailer launches. Austin Business Journal. Retrieved from

http://www.bizjournals.com/austin/stories/2008/01/14/story5.html?page=1 


\section{Appendix A}

\section{RunTex Timeline}

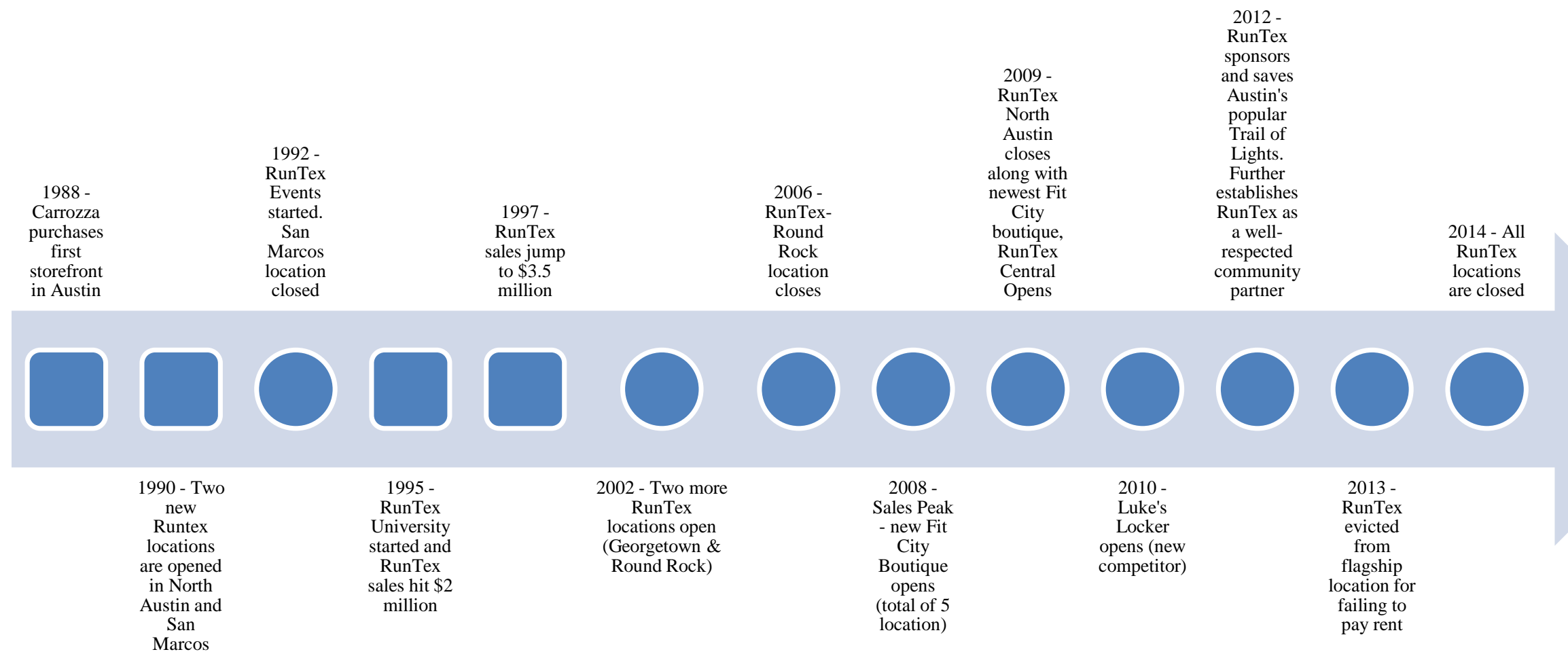




\section{Appendix B}

\section{RunTex's Most Popular Locations}

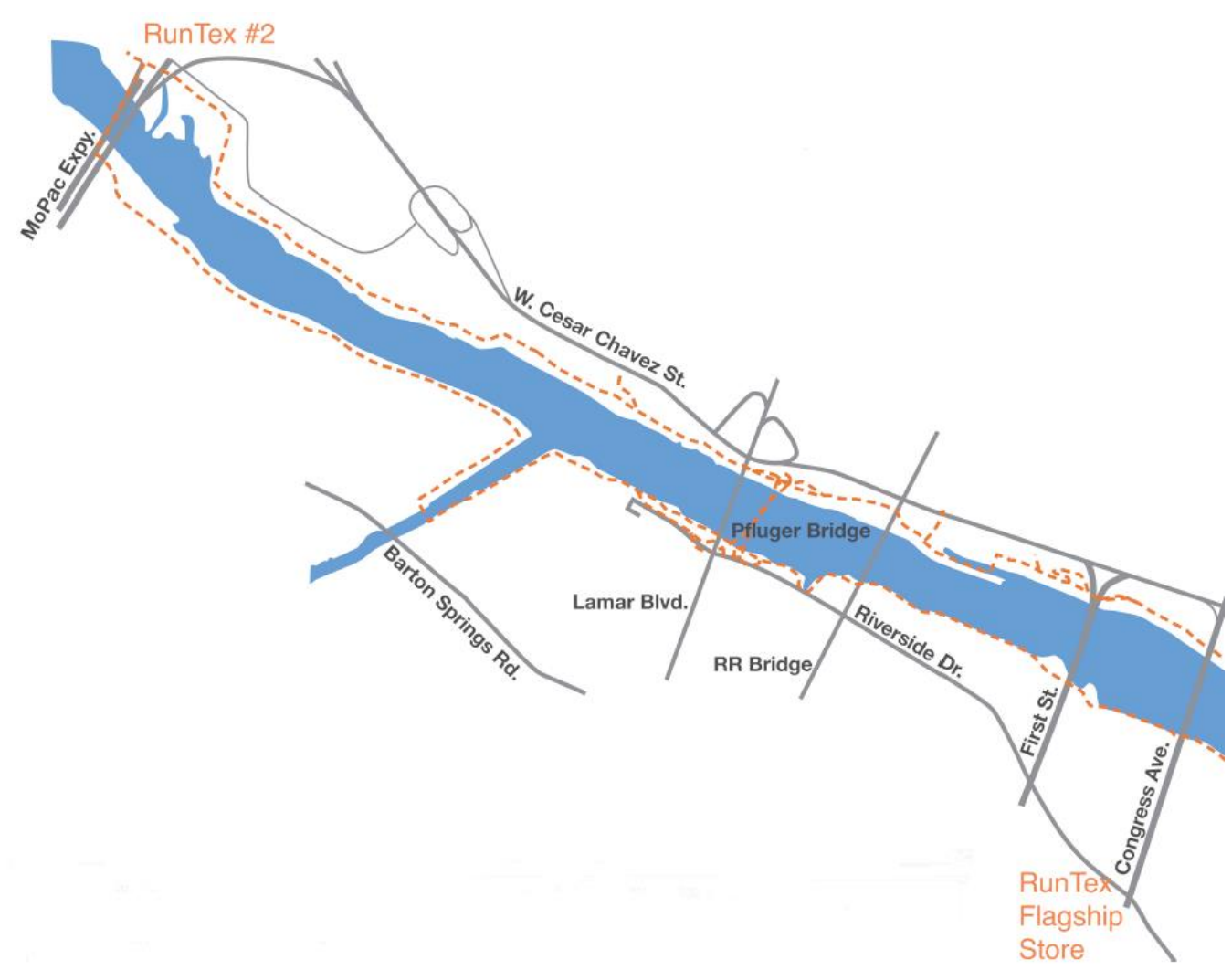

Running Trail

Mopac to Congress Loop is approximately 5 miles

Estimated that over 1 million people use the trail annually (National Trails Training Partnership, 2009)) 


\section{Table 1}

\section{Road Race Trends}

\begin{tabular}{lrrrrrrrr} 
Year & 1990 & 1995 & 2000 & 2005 & 2010 & 2011 & 2012 & 2013 \\
\hline Female & $1,199,250$ & $2,215,520$ & $3,619,560$ & $4,494,392$ & $6,929,000$ & $7,685,700$ & $8,699,000$ & $10,844,200$ \\
Male & $3,597,750$ & $4,707,980$ & $4,998,440$ & $4,947,608$ & $6,071,000$ & $6,288,300$ & $6,835,000$ & $8,180,800$ \\
\hline Totals & $4,797,000$ & $6,923,500$ & $8,618,000$ & $9,442,000$ & $13,000,000$ & $13,974,000$ & $15,534,000$ & $19,025,000$
\end{tabular}

Source: Running USA 


\section{Table 2}

Jogging \& Running Footwear Sales in U.S. (NSGA - 2)

\begin{tabular}{|c|c|c|c|c|c|c|c|c|}
\hline & 1988 & 1998 & 2008 & 2009 & 2010 & 2011 & 2012 & 2013 \\
\hline Running Shoe & & & & & & & & \\
\hline $\begin{array}{l}\text { Units } \\
\text { Running Shoe }\end{array}$ & 25.3 million & 29.4 million & 40.0 million & 39.8 million & 37.2 million & 38.0 million & 44.6 million & 46.2 million \\
\hline $\begin{array}{l}\text { Dollars } \\
\text { Sales Channels - } \\
\text { \% of Units }\end{array}$ & 987 million & 1.47 billion & 2.31 billion & 2.36 billion & 2.31 billion & 2.46 billion & 3.03 billion & 3.12 billion \\
\hline $\begin{array}{l}\text { Discount Stores } \\
\text { General Sporting }\end{array}$ & $16.00 \%$ & $14.80 \%$ & $12.80 \%$ & $22.00 \%$ & $21.40 \%$ & $18.50 \%$ & $19.80 \%$ & $20.40 \%$ \\
\hline $\begin{array}{l}\text { Goods } \\
\text { Specialty } \\
\text { Athletic }\end{array}$ & $22.00 \%$ & $15.90 \%$ & $16.30 \%$ & $20.20 \%$ & $22.50 \%$ & $23.30 \%$ & $22.40 \%$ & $22.60 \%$ \\
\hline Footwear & $22.10 \%$ & $22.10 \%$ & $16.00 \%$ & $17.60 \%$ & $16.20 \%$ & $19.60 \%$ & $18.00 \%$ & $14.10 \%$ \\
\hline Online Internet & - & - & $9.40 \%$ & $10.90 \%$ & $12.20 \%$ & $12.50 \%$ & $17.50 \%$ & $18.10 \%$ \\
\hline Factory Outlet & - & $7.00 \%$ & $7.40 \%$ & $7.70 \%$ & $4.50 \%$ & $5.70 \%$ & $4.90 \%$ & $4.90 \%$ \\
\hline Family Footwear & $12.40 \%$ & $10.40 \%$ & $11.00 \%$ & $7.20 \%$ & $6.30 \%$ & $6.40 \%$ & $4.10 \%$ & $6.70 \%$ \\
\hline Department & & & & & & & & \\
\hline $\begin{array}{l}\text { Stores } \\
\text { Specialty Sport }\end{array}$ & $17.70 \%$ & $16.10 \%$ & $19.20 \%$ & $6.70 \%$ & $8.80 \%$ & $7.20 \%$ & $7.40 \%$ & $7.00 \%$ \\
\hline Shops & $3.00 \%$ & $4.90 \%$ & $4.70 \%$ & $4.10 \%$ & $4.70 \%$ & $5.20 \%$ & $4.40 \%$ & $3.90 \%$ \\
\hline Mail Order & $2.60 \%$ & $5.70 \%$ & $1.40 \%$ & $1.40 \%$ & $1.80 \%$ & $0.40 \%$ & $1.10 \%$ & $0.80 \%$ \\
\hline Total & $95.80 \%$ & $96.90 \%$ & $98.20 \%$ & $97.80 \%$ & $98.40 \%$ & $98.80 \%$ & $99.60 \%$ & $98.50 \%$ \\
\hline
\end{tabular}

Note: sales from miscellaneous/other outlets are not included so the total does not sum to $100 \%$

Source: National Sporting Goods Association 